$\mathrm{DE}$

M E D I C I N A

T R O P I C A L

$\mathrm{DE}$

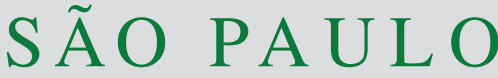

JOURNAL OF THE SÃO PAULO INSTITUTE OF TROPICAL MEDICINE

1Universidad Autónoma de Yucatán, Centro de Investigaciones Regionales Dr. Hideyo Noguchi, Laboratorio de Arbovirología, Mérida, Yucatán, México

${ }^{2}$ Instituto Nacional de Medicina Tropical Puerto Iguazú, Misiones, Argentina

Universidad Juárez Autónoma de Tabasco Laboratorio de Enfermedades Tropicales y Transmitidas por Vector, Villahermosa, Tabasco, México

${ }^{4}$ lowa State University, College of Veterinary Medicine, Ames, lowa, USA

${ }^{5}$ Hospital Infantil de México Federico Gómez, Ciudad de México, México

Correspondence to: Julián E. GarcíaRejón

Universidad Autónoma de Yucatán, Centro de Investigaciones Regionales Dr. Hideyo Noguchi, Laboratorio de Arbovirología, Calle $96 \mathrm{~s} / \mathrm{n}$ x Av. Jacinto Canek y 47 Fraccionamiento, Paseo de las Fuentes, CP 97225, Mérida, Yucatán, México

E-mail: julian.garcia@correo.uady.mx

Received: 11 July 2018

Accepted: 21 November 2018

\section{Entomological and virological surveillance for dengue virus in churches in Merida, Mexico}

\author{
Carlos Marcial Baak-Baak ${ }^{\circledR 1}$, Nohemi Cigarroa-Toledo ${ }^{\circledR 1}$, Angelica \\ Pech-May ${ }^{\circledR 2}$, Guadalupe A. Cruz-Escalona ${ }^{\circledR 1}$, Rosa C. Cetina-Trejo ${ }^{\circledR 1}$, \\ Julio C. Tzuc-Dzul ${ }^{\circledR 1}$, Lourdes Gabriela Talavera-Aguilar ${ }^{\circledR 1}$, Suemy Flores- \\ Ruiz $^{\circledR}$, , Carlos Machain-Williams ${ }^{\circledR 1}$, Oswaldo Margarito Torres-Chable ${ }^{\circledR 3}$, \\ Bradley J. Blitvich ${ }^{\circledR} 4$, Jorge Mendez-Galvan ${ }^{\circledR 5}$, Julian E. Garcia-Rejon ${ }^{\circledR 1}$
}

\section{ABSTRACT}

This study was designed to assess whether churches in endemic dengue districts in Merida, Mexico provide suitable breeding habitats for mosquitoes and are potential sites for dengue virus (DENV) transmission. Churches were inspected for immature and adult mosquitoes once every week from November 2015 to October 2016. A total of 10,997 immatures of five species were collected. The most abundant species were Aedes aegypti $(6,051)$ and Culex quinquefasciatus $(3,018)$. The most common source of immature Ae. aegypti were buckets followed by disposable containers. Adult collections yielded 21,226 mosquitoes of nine species. The most common species were $C x$. quinquefasciatus $(15,215)$ and Ae. aegypti $(3,902)$. Aedes aegypti were found all year long. Female Ae. aegypti $(1,380)$ were sorted into pools (166) and assayed for flavivirus RNA by RT-PCR and Sanger sequencing. Two pools were positive for DENV (DENV-1 and 2). In conclusion, we demonstrated that some churches in Merida are infested with mosquitoes all year long and they potentially serve as sites for DENV transmission and should therefore be considered for inclusion in mosquito and arboviruses control and surveillance efforts.

KEYWORDS: Aedes aegypti. Flavivirus. Mosquitoes. Dengue.

\section{INTRODUCTION}

Dengue virus (DENV; Flaviviridae, Flavivirus) represents an enormous problem in terms of human morbidity and economic burden. Globally, DENV is responsible for approximately 1.14 million disability-adjusted life-years annually ${ }^{1}$. In Mexico, an estimated 139,000 symptomatic DENV infections occur each year, with a mean of 65 disability-adjusted life years per million individuals ${ }^{2}$. There are four serotypes of DENV (DENV-1 to 4). The serotypes are genetically distant from each other and can be further divided into different genotypes ${ }^{3}$. Some serotypes are more virulent than others and have been associated with increased disease severity (e.g., DENV-2 American/Asian genotype $)^{4}$. The introduction of distinct viral genotypes can trigger epidemics; thus, it is important that sequencing studies are performed so that viruses are identified and critical information on virus emergence and persistence is acquired ${ }^{5}$.

DENV is primarily transmitted to humans through the bite of Aedes aegypti ${ }^{3}$ infected females which feed almost exclusively on humans and are commonly found in households and other sites where people spend much of their time ${ }^{6}$. DENV is 
hyperendemic in Yucatan State and elsewhere in the Yucatan Peninsula in Mexico ${ }^{6,7}$, and chikungunya virus (CHIKV) also circulates in this region ${ }^{8}$. Previous studies performed inside the houses in Merida, Yucatan State, resulted in the detection of DENV- and CHIKV-infected Ae. aegypti ${ }^{6-8}$ females. Virus-infected mosquitoes have also been detected in frequently visited public locations. For example, DENVinfected Ae. aegypti were collected in schools in Merida ${ }^{9}$. In the State of San Luis Potosi, ZIKV-infected Ae. aegypti were detected in cemeteries ${ }^{10}$. It is therefore important to monitor public sites for potential arboviruses transmission.

Churches regularly receive a large influx of visitors, both locals and tourists, who could potentially become infected during their visits and introduce the virus into new areas. We have previously revealed that engorged $A e$. aegypti often occur inside churches in Merida ${ }^{11}$. Despite this, studies have not been performed to determine whether churches located in neighborhoods with a high incidence of DENV provide suitable breeding habitats for immature mosquitoes and are potential sites for virus transmission. To address these gaps in our knowledge, longitudinal entomological and virological surveillance were performed in selected churches in three endemic dengue districts of Merida. Churches were inspected regularly for the presence of mosquitoes breeding sites, the abundance and species composition of immature and adult mosquitoes were determined, and Ae. aegypti females were assayed for evidence of DENV infection.

\section{MATERIAL AND METHODS}

\section{Study sites}

Merida (population 800,000) is located in the Yucatan Peninsula of Mexico. The city has a distinct rainy (MayOctober) season and a dry season (November-April). In the rainy season, the mean rainfall is $1,000 \mathrm{~mm}$ and the mean temperature is $27.5^{\circ} \mathrm{C}$. In the dry season, the mean rainfall is $300 \mathrm{~mm}$ and the mean temperature is $25.1^{\circ} \mathrm{C}^{6}$.

The studied sites were located in three neighborhoods where high DENV transmission has been previously reported $^{6,7,9}$. The largest church in each neighborhood was selected based on the assumption that it would have more mosquitoes breeding sites and a higher abundance of immature and adult mosquitoes than other churches in the neighborhood. Church leaders provided unlimited access to the entire area, including rooms, offices, kitchens, storage rooms and gardens. It is estimated that each church is visited by at least 900 individuals each week (300 and 600 individuals on weekdays and weekends, respectively), although these numbers are higher when there are important religious holidays, festivities or celebrations (personal communication from church authorities). The neighborhoods are San Jose Tecoh, Bojorquez and Vergel III, located in Southern, Central and Eastern Merida, respectively. The first two churches are located approximately $20 \mathrm{~m}$ from the nearest houses. The church in Vergel III is located approximately $80 \mathrm{~m}$ from the nearest house. The churches are similar in size $\left(\sim 10,000 \mathrm{~m}^{2}\right)$, close to markets and 8 to $10 \mathrm{~km}$ apart from each other (Figure 1).

\section{Sampling of immature mosquitoes}

Mosquitoes were collected at each church once a week from November 2015 to October 2016. Collections were made both indoor and outdoor. Outdoor collections were primarily focused on garden areas and parking lots on church grounds. Containers were classified following the methodology of Garcia-Rejon et al. ${ }^{12}$. Immatures were removed from water-holding containers using nets, turkey basters and pipettes and placed inside plastic transportation containers labeled according to date, study site and sample identification number. Mosquitoes were individually removed from transportation containers and counted in a white tray. Immatures were allowed to emerge, then adults were identified to species ${ }^{11,12}$.

\section{Adult mosquito collections}

Adult mosquitoes were collected between 8 a.m. and 1 p.m. using a backpack-mounted aspirator (Prokopack Aspirator $^{\circledR}$, model 1419, John W. Hock Company). Each church was inspected for resting adults once every week. Indoor collections focused primarily on furniture, hanging clothes, curtains as well as dark and humid places. Outdoor collections focused primarily on garden areas and fences. The amount of time actively spent searching for resting mosquitoes at each site was 1-2 h per visit. Both adults and immatures were transported alive to the laboratory of Arbovirologia at Universidad Autónoma de Yucatán and identified according to species using stereomicroscopes and a published identification key ${ }^{13}$. Female Ae. aegypti were sorted into pools of up to 15 specimens and stored at $-80{ }^{\circ} \mathrm{C}$ until required.

\section{Mosquitoes homogenizations, RNA extractions and RT-PCR}

Pools of female adult Ae. aegypti were placed into eppendorf tubes containing $300 \mu \mathrm{L}$ of Liebovitz's L15 medium (Invitrogen, Carlsbad, CA, USA) and mechanically homogenized using sterile pestles. Homogenates were 


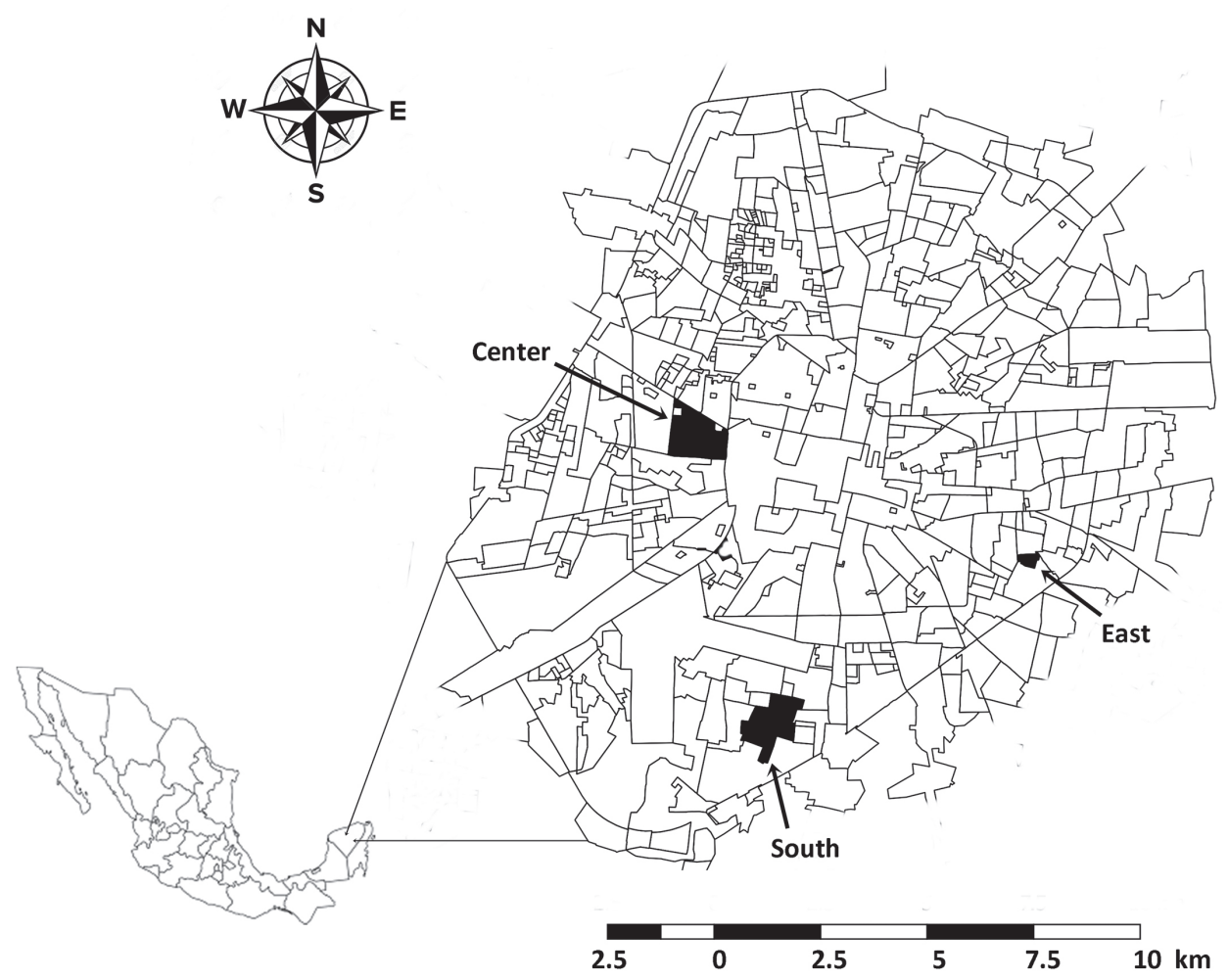

Figure 1 - Location of study sites in Merida, Yucatan, Mexico. Catholic churches were located in three neighborhoods: Bojorquez (Center), San Jose Tecoh (South) and Vergel-III (East).

centrifuged at $10,000 \times \mathrm{g}$ for $10 \mathrm{~min}$. and supernatants were collected. Total RNA was extracted from an aliquot $(100 \mu \mathrm{L})$ of each supernatant using an RNeasy kit (Qiagen, Valencia, CA, USA) and tested for flavivirus RNA by reverse transcription-polymerase chain reaction (RT-PCR) using flavivirus-specific primers (MAMD, cFD2 and FS778) which amplify an $\sim 250 \mathrm{nt}$ region of the NS5 gene ${ }^{14}$. RT-PCRs were performed in $25 \mu \mathrm{L}$ reaction volumes containing $2.5 \mu \mathrm{L}$ of total $\mathrm{RNA}, 2 \mu \mathrm{L} \mathrm{MgCl} 2$ at a concentration of $25 \mathrm{mM}, 2.5 \mu \mathrm{L}$ of $5 \mathrm{x}$ reaction buffer, $0.2 \mu \mathrm{L}$ of dNTPs, $0.5 \mathrm{U}$ of Taq polymerase (Invitrogen), $0.5 \mu \mathrm{L}$ of each primer at a concentration of $10 \mathrm{mM}$ and $16.15 \mu \mathrm{L}$ sterile distilled water. Total RNA extracted from DENV-2infected cells was used as the positive control after reverse transcription. As the negative control, molecular biology grade water was used instead of total RNA. Amplification conditions are as follows: an initial denaturation of $95^{\circ} \mathrm{C}$ for 1 minute, followed by 35 cycles, each one consisting of $1 \mathrm{~min}$ at $95^{\circ} \mathrm{C}, 1.5 \mathrm{~min}$ at $75^{\circ} \mathrm{C}$, and $1 \mathrm{~min}$ at $72{ }^{\circ} \mathrm{C}$ and then a final extension for $7 \mathrm{~min}$ at $72{ }^{\circ} \mathrm{C}$. Amplicons were visualized on $2 \%$ agarose gels with $0.5 \mu \mathrm{g} / \mathrm{mL}$ ethidium bromide using a Doc ${ }^{\mathrm{TM}} \mathrm{XR}+$ Gel Documentation System. RT-PCR products were purified using the Zymoclean DNA recovery kit Cat (Zymo Research, Irvine, CA, USA) and sequenced using a 3500xL DNA sequencer (Applied Biosystems, Foster City, CA, USA). Sequences were manually aligned and edited using the Bioedit v.7.0.9 software $^{15}$ and the Mega v.7 software ${ }^{16}$.

\section{Statistical analysis}

Entomological indices estimated in this study are as follows: 1) the container index, defined as the percentage of water-filled containers with immature Ae. aegypti and 2) the pupal index, defined as the percentage of containers with Ae. aegypti pupae when compared to containers with Ae. aegypti immatures (larvae and/or pupae). A MannWhitney $\mathrm{U}$ test was used to compare the number of female Ae. aegypti by season because the data did not meet the assumptions of normality and homogeneity of variances. The statistical analysis was performed using the IBM SPSS Statistics version 22 software for Windows (IBM Corporation, Armonk, NY) and results were considered significant when $P \leq 0.05$.

\section{RESULTS}

\section{Immature mosquito collections}

The total number of containers observed in the entire study was 2,918 (Table 1). This tally is based on the assumption that one container can be counted more than 
Table 1 - Collections of $A$ e. aegypti immatures in churches of Merida, Yucatan by season and container type, from November 2015 to October 2016.

\begin{tabular}{|c|c|c|c|c|c|c|}
\hline \multirow{2}{*}{ Type of container } & \multirow{2}{*}{$\begin{array}{c}\text { Total } \mathrm{n}^{\circ} \text { container } \\
\text { observations/with }- \\
\text { water }\end{array}$} & \multicolumn{2}{|c|}{$\begin{array}{c}N^{\circ} \text { water-filled containers } \\
\text { with immatures }\end{array}$} & \multirow{2}{*}{$\begin{array}{l}\text { Water }(\mathrm{L}) \\
\text { per container } \\
\text { (mean } \pm \mathrm{SD})\end{array}$} & \multicolumn{2}{|c|}{ Total $n^{\circ}$ of immatures } \\
\hline & & $\begin{array}{l}\text { Larvae and } \\
\text { pupae }\end{array}$ & ${ }^{\text {b }}$ Pupae & & Larvae & Pupae \\
\hline \multicolumn{7}{|l|}{ Rainy season } \\
\hline Buckets & $242 / 129$ & 25 & 14 & $4.18 \pm 4.38$ & 2,898 & 211 \\
\hline Disposable containers & $1,099 / 379$ & 13 & 7 & $0.80 \pm 4.39$ & 580 & 30 \\
\hline a'Larger containers & $97 / 35$ & 13 & 4 & $1.81 \pm 3.32$ & 922 & 25 \\
\hline Vases & $57 / 34$ & 1 & 1 & $1.80 \pm 0.0$ & 40 & 8 \\
\hline Flower pots & $172 / 38$ & 1 & 1 & $1.15 \pm 0.0$ & 115 & 5 \\
\hline Tires & $11 / 2$ & 1 & 0 & $0.35 \pm 0.0$ & 88 & 0 \\
\hline Discarded toilet & $6 / 2$ & 0 & 0 & $2.82 \pm 1.44$ & 0 & 0 \\
\hline Storm water-drains & $68 / 45$ & 1 & 0 & $78.33 \pm 153.57$ & 88 & 0 \\
\hline Subtotal & $1,752 / 664$ & 55 & 27 & $2.63 \pm 4.18$ & 4,731 & 279 \\
\hline \multicolumn{7}{|l|}{ Dry season } \\
\hline Buckets & $205 / 72$ & 6 & 2 & $7 \pm 6.04$ & 785 & 33 \\
\hline Disposable containers & $692 / 31$ & 0 & 0 & $0.46 \pm 0.83$ & 0 & 0 \\
\hline aLarger containers & $52 / 8$ & 4 & 1 & $3.30 \pm 1.56$ & 220 & 3 \\
\hline Vases & $3 / 3$ & 0 & 0 & $0.81 \pm 0.44$ & 0 & 0 \\
\hline Flower pots & $157 / 15$ & 0 & 0 & $0.95 \pm 0.80$ & 0 & 0 \\
\hline Tires & $2 / 0$ & 0 & 0 & 0 & 0 & 0 \\
\hline$\underline{\text { Storm water-drains }}$ & $55 / 11$ & 0 & 0 & $21.82 \pm 18.34$ & 0 & 0 \\
\hline Subtotal & $1,166 / 140$ & 10 & 3 & $5.15 \pm 4.61$ & 1,005 & 36 \\
\hline Total & $2,918 / 804$ & 65 & 30 & $3.02 \pm 4.31$ & 5,736 & 315 \\
\hline
\end{tabular}

With a capacity $>5$ liters; ${ }^{\text {a }}$ Number of containers with pupae

once (i.e. one count for every visit in which the container was observed). Water was detected during $27.5 \%(804 / 2,918)$ of the container observations and $8.1 \%(65 / 804)$ yielded immatures. A total of 10,997 immatures of five species were collected (Table 2). The most abundant species was Ae. aegypti $(6,051)$ followed by Culex quinquefasciatus Say (3,018), Culex nigripalpus Theobald (1,894), Culex thriambus Dyar (26), and Culex interrogator Dyar and Knab (8).

Seven-fold more immatures were collected in the rainy season $(9,628)$ compared to the dry season $(1,369$, Table 2). Analysis of the data at the species level also revealed that immature Ae. aegypti were more common in the rainy season. A total of 1,758 container observations were made in the rainy season. Water was detected in $37.8 \%(664 / 1,758)$ of the container observations and $8.2 \%$ (55/664) yielded immatures (Table 1). The pupal index was calculated as $49.1 \%(27 / 55)$. In the dry season, 1,166 container observations were made. Of these, $12.0 \%$ $(140 / 1,166)$ revealed water and $7.1 \%(10 / 140)$ yielded immatures. The pupal index was calculated as $30.0 \%$ (3/10) (Table 1). Buckets were the most common source of Ae. aegypti during both seasons and accounted for $64.9 \%$ $(3,927 / 6,051)$ of those collected. Disposable containers and
Table 2 - Abundance and species composition of immature mosquitoes collected in churches of Merida, Yucatan, from November 2015 to October 2016.

\begin{tabular}{lccc}
\hline \multirow{2}{*}{ Mosquito species } & Church & \multicolumn{2}{c}{$\begin{array}{c}\text { Total } \mathrm{n}^{\circ} \text { of immatures } \\
\text { collected }\end{array}$} \\
\cline { 3 - 4 } & & Larvae & Pupae \\
\hline Rainy season & & & \\
Aedes aegypti & Vergel III & 4,257 & 242 \\
$\begin{array}{l}\text { Culex } \\
\text { quinquefasciatus }\end{array}$ & Vergel III & 2,648 & 68 \\
$\begin{array}{l}\text { Culex nigripalpus } \\
\text { Culex interrogator }\end{array}$ & Vergel III & 1,847 & 47 \\
Aedes aegypti & Vergel III & 8 & 0 \\
Aedes aegypti & San Jose & 67 & 8 \\
\hline Subtotal & Tecoh & 407 & 29 \\
\hline Dry season & Bojorquez & 9,234 & 394 \\
Aedes aegypti & Vergel III & 994 & 9 \\
$\begin{array}{l}\text { Culex } \\
\text { quinquefasciatus }\end{array}$ & Vergel III & 291 & 11 \\
Culex thriambus & Vergel III & 26 & 0 \\
Aedes aegypti & San Jose & 11 & 27 \\
\hline Subtotal & Tecoh & 1,322 & 47 \\
\hline Total & & 10,556 & 441 \\
\hline & & & \\
\hline
\end{tabular}


larger containers were the next most common sources of $A e$. aegypti at both times of the year. Ae. aegypti were present in every container that held immatures.

When collections were grouped by church, $95.0 \%$ $(10,448 / 10,997)$ of mosquito immatures were collected in Vergel III. Five species were collected in this church. The most abundant species in Vergel III was Ae. aegypti $(5,502)$ followed by $C x$. quinquefasciatus $(3,018)$. Sixty breeding sites of Ae. aegypti were registered in Vergel III, with 28 buckets, 16 larger containers and 13 disposable containers yielding 3453, 993 and 755 immatures, respectively. The pupal index was calculated as $43.3 \%$ (26/60). In Bojorquez and San Jose Tecoh, one and four breeding sites were registered, respectively.

\section{Adult mosquito collections}

In total, 21,226 adult mosquitoes (13,518 males and 7,708 females) of nine species were collected (Table 3). Of the females collected, the most abundant species was $C x$. quinquefasciatus $(4,686)$ followed by Ae. aegypti $(1,380)$, Aedes taeniorhynchus (Wiedemann) $(1,172)$ and Cx. nigripalpus (363) which together accounted $98.6 \%$ $(7,601 / 7,708)$ of the adults. Cx. quinquefasciatus was common during both the rainy and dry seasons whereas the other three species were far more abundant in the rainy season.

Significant statistical difference in the number of Ae. aegypti females per season was observed $(\mathrm{Z}=-0.57$,

Table 3 - Abundance and species composition of adult mosquitoes collected in churches of Merida, Yucatan from November 2015 to October 2016.

\begin{tabular}{|c|c|c|c|c|c|c|}
\hline \multirow{2}{*}{ Species } & \multirow{2}{*}{ Church } & \multicolumn{2}{|c|}{ Total $n^{\circ}$ of adults collected } & \multicolumn{3}{|c|}{ Blood feeding status } \\
\hline & & Males & Females & Unfed & Fed & Gravid \\
\hline \multicolumn{7}{|l|}{ Rainy season } \\
\hline Ae. aegypti & Vergel-III & 2,036 & 1,029 & 375 & 474 & 180 \\
\hline Ae. taeniorhynchus & Vergel-III & 272 & 1,039 & 410 & 280 & 349 \\
\hline Ae. trivittatus & Vergel-III & 0 & 32 & 9 & 5 & 18 \\
\hline Cx. coronator & Vergel-III & 0 & 1 & 1 & 0 & 0 \\
\hline Cx. interrogator & Vergel-III & 21 & 67 & 53 & 5 & 9 \\
\hline Cx. nigripalpus & Vergel-III & 129 & 321 & 185 & 12 & 124 \\
\hline Cx. quinquefasciatus & Vergel-III & 4,766 & 1,813 & 974 & 505 & 334 \\
\hline Cx. stigmatosoma & Vergel-III & 0 & 1 & 0 & 1 & 0 \\
\hline Ps. ferox & Vergel-III & 0 & 3 & 1 & 1 & 1 \\
\hline Ae. aegypti & San Jose Tecoh & 7 & 26 & 10 & 10 & 6 \\
\hline Cx. quinquefasciatus & San Jose Tecoh & 87 & 33 & 14 & 7 & 12 \\
\hline Ae. taeniorhynchus & San Jose Tecoh & 0 & 6 & 4 & 2 & 0 \\
\hline Ae. aegypti & Bojorquez & 193 & 123 & 52 & 52 & 19 \\
\hline Cx. quinquefasciatus & Bojorquez & 184 & 119 & 55 & 47 & 17 \\
\hline Ae. taeniorhynchus & Bojorquez & 34 & 115 & 69 & 38 & 8 \\
\hline Ae. trivittatus & Bojorquez & 0 & 3 & 2 & 0 & 1 \\
\hline Subtotal & & 7,729 & 4,731 & 2,214 & 1,439 & 1,078 \\
\hline \multicolumn{7}{|l|}{ Dry season } \\
\hline Ae. aegypti & Vergel-III & 281 & 187 & 79 & 76 & 32 \\
\hline Ae. taeniorhynchus & Vergel-III & 9 & 12 & 6 & 2 & 4 \\
\hline Cx. nigripalpus & Vergel-III & 2 & 42 & 35 & 2 & 5 \\
\hline Cx. quinquefasciatus & Vergel-III & 5,421 & 2,680 & 1,925 & 609 & 146 \\
\hline Ae. aegypti & San Jose Tecoh & 2 & 7 & 5 & 1 & 1 \\
\hline Cx. quinquefasciatus & San Jose Tecoh & 47 & 23 & 10 & 7 & 6 \\
\hline Ae. aegypti & Bojorquez & 3 & 8 & 5 & 2 & 1 \\
\hline Cx. quinquefasciatus & Bojorquez & 24 & 18 & 10 & 3 & 5 \\
\hline Subtotal & & 5,789 & 2,977 & 2,075 & 702 & 200 \\
\hline Total & & 13,518 & 7,708 & 4,289 & 2,141 & 1,278 \\
\hline
\end{tabular}


$\mathrm{p}=0.001$ ). Approximately six-fold more Ae. aegypti females were collected in the rainy season compared to the dry season (Table 3). Of the 1,178 Ae. aegypti females collected during the rainy season, 536 were identified as fed, 437 as unfed and 205 as gravid (Table 4). In the dry season, 202 Ae. aegypti females were collected with 89 identified as unfed, 79 as fed and 34 as gravid.

Vergel III was the most common source of adult mosquitoes; 95\% (12,937 males and 7,227 females) of adults of nine species were collected (Table 3). Of the 7,227 females collected, the most abundant species was Cx. quinquefasciatus $(4,493)$ followed by Ae. aegypti (1,216), Ae. taeniorhynchus (1,051), Cx. nigripalpus (363), Cx. interrogator (67), Ae. trivittatus (32), Cx. thriambus (26), Ps. ferox (3), Cx. coronator (1) and Cx. stigmatosoma (1). Eighty-eight percent $(1,216 / 1,380)$ of Ae. aegypti females was collected in this site.

\section{Detection of DENV in Ae. aegypti}

Adult Ae. aegypti females were sorted into 166 pools and analyzed for flavivirus RNA by RT-PCR and Sanger sequencing. Two (1.2\%) pools were positive (Table 4 ). One pool contained DENV-1 and the other contained DENV-2 (GenBank accession number KU232287 and KJ189370, respectively). The DENV minimal infection rate (MIR) for Ae. aegypti females (expressed as the number of positive mosquito pools per 1,000 mosquitoes tested) was 1.5. Both DENV-positive pools were collected inside the church in Vergel III. The DENV-1-positive pool consisted of mosquitoes collected in a storage room. The DENV-2positive pool consisted of mosquitoes collected inside the nave, the main area of the church where the congregation is held. Both pools comprised of mosquitoes were collected in October 2016.

\section{DISCUSSION}

Vergel III represented a higher potential entomological risk than the other investigated churches. The pupal index in this church over the entire study period was $43.3 \%$, peaking at $47.0 \%$ in the rainy season. Pupae are considered a better proxy than other life stages for estimating mosquitoes abundance $^{17}$. Based on the operative criteria of the Mexican Ministry of Health, a pupal index greater than $5 \%$ is regarded as an emergency level status that requires immediate action (i.e. treatment or elimination of breeding sites $)^{18}$. Adult Ae. aegypti were also more abundant at Vergel III compared to the other churches in this study. It has previously been reported that greater mosquitoes abundance increases the risk of human DENV transmission ${ }^{7}$. Both pools of DENVinfected Ae. aegypti were detected in the church of Vergel III. Similarly, in Iquitos, Peru, abundance of Ae. aegypti females were better proxies for DENV risk ${ }^{19}$.

DENV-infected Ae. aegypti have been detected inside schools and houses in Merida ${ }^{6,7,9}$. Water-filled containers are common in Merida and contribute to the high abundance of mosquitoes ${ }^{12,20}$. It should also be noted that Ae. aegypti with Ile 1,016 and Cys 1,534 mutations in their voltage gated sodium channel gene have been detected in Merida. These mutations are associated with pyrethroid resistance ${ }^{21,22}$. Thus, increased vector control is required in this region. One way to achieve this goal is through increased community intervention. In this study, we educated church workers on mosquitoes (i.e. their life cycle and role in arbovirus transmission) and

Table 4 - Detection of dengue virus RNA in adult Ae. aegypti females in churches of Merida from November 2015 to October 2016.

\begin{tabular}{lccccccc}
\hline $\begin{array}{l}\text { Area within } \\
\text { Merida city }\end{array}$ & Neighborhoods & $\begin{array}{c}\text { No total } \\
\text { females }\end{array}$ & $\begin{array}{c}\text { No total } \\
\text { unfed }\end{array}$ & $\begin{array}{c}\text { No total } \\
\text { fed }\end{array}$ & $\begin{array}{c}\text { No total } \\
\text { gravid }\end{array}$ & $\begin{array}{c}\text { No of pools } \\
\text { tested }\end{array}$ & $\begin{array}{c}\text { No of positive } \\
\text { pools for DENV }\end{array}$ \\
\hline Rainy season & Vergel-III & 1,029 & 375 & 474 & 180 & 125 & 2 \\
$\begin{array}{l}\text { East } \\
\text { South }\end{array}$ & $\begin{array}{c}\text { San Jose Tecoh } \\
\text { Center }\end{array}$ & 26 & 10 & 10 & 6 & 3 & 0 \\
\hline Subtotal & Bojorquez & 123 & 52 & 52 & 19 & 14 & 0 \\
\hline Dry season & & 1,178 & 437 & 536 & 205 & 142 & 2 \\
\hline East & Vergel-III & 187 & 79 & 76 & 32 & 22 & 0 \\
South & San Jose Tecoh & 7 & 5 & 1 & 1 & 1 & 0 \\
Center & Bojorquez & 8 & 5 & 2 & 1 & 1 & 0 \\
\hline Subtotal & & 202 & 89 & 79 & 34 & 24 & 0 \\
\hline Total & & 1,380 & 526 & 615 & 239 & 166 & 2 \\
\hline
\end{tabular}


recommended that church visitors should use personal protection against mosquitoes (e.g. repellents).

Environmental conditions may influence the mosquitoes population size. High populations of Ae. aegypti in the rainy season have been previously reported in Yucatan State ${ }^{6,9,20}$. Seven-fold more immature Ae. aegypti were collected in the rainy season compared to the dry season presumably due to an increase in the number of water-filled containers. A high number of breeding sites and immature Ae. aegypti were identified in Vergel III. Buckets followed by disposable containers were the most common breeding sites for Ae aegypti and most were filled by rain water. Disposable containers were also common breeding sites for Ae. aegypti in and around houses in Merida ${ }^{6,12}$. Previous studies in Merida have also shown that tires and flower pots are common breeding sites in vacant lots and parking lots, respectively ${ }^{20}$. Storm-water drains along streets and sidewalks harbor many species of mosquitoes throughout the year ${ }^{23}$.

It is important to highlight two characteristics of Vergel III: $88 \%$ of Ae. aegypti females were collected in this church and it is located approximately $80 \mathrm{~m}$ from the nearest house. We speculate that most Ae. aegypti in Vergel III had not traveled there from the houses. Aedes aegypti has a limited flight range; it is generally accepted that females do not fly more than 50-100 $\mathrm{m}$ in their entire lifetime ${ }^{24}$ and that they remain close to human hosts and oviposition sites $^{12,20}$. Therefore, humans potentially contribute more than the vector for the movement of DENV to new areas. To the best of our knowledge, this is the first study to detect DENV-infected Ae. aegypti in church environments. Mosquito-based surveillance for arboviruses can be used to detect viruses prior to the occurrence of outbreaks as human infections are often asymptomatic ${ }^{2,3}$. The DENV MIR in this study was 1.5 which is considerably lower than the 4.6 reported in Merida schools ${ }^{9}$. However, our results are similar to earlier studies performed inside the houses of dengue patients ${ }^{6,7}$.

Nine mosquito species were collected in Vergel III, and the most common species was Ae. aegypti, consistent with previous studies performed in Merida. Diversity of mosquito species represented $17.3 \%$ (9/52) of mosquito fauna identified in Yucatan State ${ }^{25}$. Other mosquito species involved in arbovirus disease transmission were also identified including $C x$. interrogator, $C x$. quinquefasciatus, $C x$. nigripalpus, $C x$. stigmatosoma and $C x$. thriambus which are competent vectors of West Nile virus and St. Louis encephalitis virus ${ }^{26,27}$. West Nile virus has been detected in Cx. quinquefasciatus in Nuevo Leon, Northern Mexico $^{28}$ and was abundant in the present study. West Nile virus has also been detected in $C x$. nigripalpus and
$C x$. interrogator in Chiapas, Southern Mexico ${ }^{27}$. The alphavirus, Venezuelan equine encephalitis virus, was detected in $C x$. coronator in Veracruz State ${ }^{29}$. Several orthobunyaviruses, including Cache Valley virus were isolated from Ae. taeniorhynchus in Yucatan State ${ }^{30}$. It is therefore important that mosquito control efforts in Merida do not focus only on Ae. aegypti.

Our study provides additional evidence that public sites harbor infected disease vectors. Previous studies performed in Merida identified DENV-infected Ae. aegypti in schools ${ }^{9}$ and a cemetery ${ }^{31}$. DENV- and ZIKV-infected Ae. aegypti and Ae. albopictus were identified in cemeteries in San Luis Potosi in Central-Northern Mexico ${ }^{10}$. In Belo Horizonte, Brazil, both DENV and ZIKV were detected in Ae. aegypti collected at a university ${ }^{32}$. Furthermore, La Crosse virus was detected in Aedes triseriatus in cemeteries in Tennessee, $\mathrm{USA}^{33}$. However, it is important to note that our study has several limitations. For example, a small number of churches were surveyed and those from areas with low arbovirus transmission were not included. Therefore, it is not known if our findings are typical for churches in Merida or elsewhere in Mexico. Nevertheless, the findings from this study and previous reports demonstrate the need to monitor public sites to control disease transmission.

\section{CONFLICT OF INTERESTS}

\section{None}

\section{FUNDING}

The study was supported in part by the Consejo Nacional de Ciencia y Tecnologia de México, Grant Problemas Nacionales (PDCPN 2014-247005).

\section{ACKNOWLEDGMENTS}

We thank the church leaders for their permission to work, providing unlimited access to the entire area for mosquitoes collections.

\section{AUTHORS' CONTRIBUTIONS}

Carlos M. Baak-Baak and Julian García-Rejón conceived and designed the study. Nohemi Cigarroa-Toledo and Angelica Pech-May carried out the phylogenetic analysis. Guadalupe A. Cruz-Escalona, Rosa C. Cetina-Trejo, Julio C. Tzuc-Dzul, Lourdes G. Talavera-Aguilar, and Suemy Flores-Ruiz carried out the fieldwork and the labwork and analysis and interpretation of these data. Oswaldo M. Torres-Chable and Carlos Machain-Williams drafted the 
manuscript. Bradley J. Blitvich and Jorge Méndez-Galván critically revised the manuscript for intellectual content. All authors read and approved the final manuscript.

\section{REFERENCES}

1. Stanaway JD, Shepard DS, Undurraga EA, Halasa YA, Coffeng LE, Brady OJ, et al. The global burden of dengue: an analysis from the Global Burden of Disease Study 2013. Lancet Infect Dis. 2016;16:712-23.

2. Undurraga EA, Betancourt-Cravioto M, Ramos-Castañeda J, Martínez-Vega R, Méndez-Galván J, Gubler DJ, et al. Economic and disease burden of dengue in Mexico. PLoS Negl Trop Dis. 2015;9:e0003547.

3. Chen R,Vasilakis N. Dengue - quo tu et quo vadis? Viruses. 2011;3:1562-608.

4. Rico-Hesse R. Microevolution and virulence of dengue viruses. Adv Virus Res. 2003;59:315-41.

5. Díaz FJ, Black WC $4^{\text {th }}$, Farfán-Ale JA, Loroño-Pino MA, Olson KE, Beaty BJ. Dengue virus circulation and evolution in Mexico: a phylogenetic perspective. Arch Med Res. 2006;37:760-73.

6. Garcia-Rejon JE, Loroño-Pino MA, Farfán-Ale JA, Flores-Flores L, Del Pilar Rosado-Paredes E, Rivero-Cardenas N, et al. Dengue virus-infected Aedes aegypti in the home environment. Am J Trop Med Hyg. 2008;79:940-50.

7. Eisen L, Garcia-Rejón JE, Gómez-Carro S, Nájera Vázquez MR, Keefe TJ, Beaty BJ, et al. Temporal correlations between mosquito-based dengue virus surveillance measures or indoor mosquito abundance and dengue case numbers in Merida City, Mexico. J Med Entomol. 2014;51:885-90.

8. Cigarroa-Toledo N, Blitvich BJ, Cetina-Trejo RC, Talavera-Aguilar LG, Baak-Baak CM, Torres-Chablé OM, et al. Chikungunya virus in febrile humans and Aedes aegypti mosquitoes, Yucatan, Mexico. Emerg Infect Dis. 2016;22:1804-7.

9. Garcia-Rejón JE, Loroño-Pino MA, Farfán-Ale JA, Flores-Flores LF, López-Uribe MP, Najera-Vazquez MR, et al. Mosquito infestation and dengue virus infection in Aedes aegypti females in schools in Merida, Mexico. Am J Trop Med Hyg. 2011;84:489-96.

10. Huerta H, González-Roldán JF, Sánchez-Tejeda G, CorreaMorales F, Romero-Contreras FE, Cárdenas-Flores R, et al. Detection of Zika virus in Aedes mosquitoes from Mexico. Trans Royal Soc Trop Med Hyg. 2017;111:328-31.

11. Baak-Baak CM, Ulloa-Garcia A, Cigarroa-Toledo N, Tzuc-Dzul JT, Machain-Williams C, Torres-Chable OM, et al. Blood feeding status, gonotrophic cycle and survivorship of Aedes (Stegomyia) aegypti (L.) (Diptera: Culicidae) caught in churches from Merida, Yucatan, Mexico. Neotrop Entomol. 2017;46:622-30.

12. García-Rejón JE, López-Uribe MP, Loroño-Pino MA, Farfán-Ale
JA, Najera-Vazquez MR, Lozano-Fuentes S, et al. Productive container types for Aedes aegypti immatures in Merida, Mexico. J Med Entomol. 2011;48:644-50.

13. Carpenter SJ, LaCasse WJ. Mosquitoes of North America (North of Mexico). Berkeley: University of California; 1955.

14. Scaramozzino N, Crance JM, Jouan A, DeBriel DA, Stoll F, Garin $\mathrm{D}$, et al. Comparison of flavivirus universal primer pairs and development of a rapid, highly sensitive heminested reverse transcription-PCR assay for detection of flaviviruses targeted to a conserved region of the NS5 gene sequences. J Clin Microbiol. 2001;39:1922-7.

15. Alzohairy AM. BioEdit: an important software for molecular biology. GERF Bull Biosci. 2011;2:60-1.

16. Kumar S, Stecher G, Tamura K. MEGA7: Molecular Evolutionary Genetics Analysis version 7.0 for bigger datasets. Mol Biol Evol. 2016;33:1870-4.

17. Focks DA, Chadee DD. Pupal survey: an epidemiologically significant surveillance method for Aedes aegypti: an example using data from Trinidad. Am J Trop Med Hyg. 1997;56:15967.

18. México. Secretaria de Salud. Guía metodológica de estudios entomológicos para fase larvaria y pupal. [cited 2018 Jul 11]. Available from: http://www.cenaprece.salud. gob.mx/programas/interior/vectores/descargas/pdf/guia_ entomologica_fase_larvaria_pupal.pdf

19. Cromwell EA, Stoddard ST, Barker CM, Van Rie A, Messer WB, Meshnick SR, et al. The relationship between entomological indicators of Aedes aegypti abundance and dengue virus infection. PLoS Negl Trop Dis. 2017;11:e0005429.

20. Baak-Baak CM, Arana-Guardia R, Cigarroa-Toledo N, LoroñoPino MA, Reyes-Solis G, Machain-Williams C, et al. Vacant lots: productive sites for Aedes (Stegomyia) aegypti (Diptera: Culicidae) in Merida City, Mexico. J Med Entomol. 2014;51:475-83.

21. Vera-Maloof FZ, Saavedra-Rodriguez K, Elizondo-Quiroga A, Lozano-Fuentes S, Black WC IV. Coevolution of the Ile1,016 and Cys1,534 mutations in the voltage gated sodium channel gene of Aedes aegypti in Mexico. PLoS Negl Trop Dis. 2015;9:e0004263.

22. Garcia-Rejon JE, Chan-Orilla JA, Cigarroa-Toledo N, ChiChim WA, Torres-Chable OM, Cruz-Escalona GA, et al. Laboratory evaluation of the Ile1, 016 mutation-effect on several life-history parameters of Aedes aegypti. Int J Mosq Res. 2018;5:112-20.

23. Arana-Guardia R, Baak-Baak CM, Loroño-Pino MA, MachainWilliams C, Beaty BJ, Eisen L, et al. Stormwater drains and catch basins as sources for production of Aedes aegypti and Culex quinquefasciatus. Acta Trop. 2014;134:33-2.

24. Reiter P. Oviposition, dispersal, and survival in Aedes aegypti: implications for the efficacy of control strategies. Vector Borne Zoonotic Dis. 2007;7:261-73. 
25. Baak-Baak CM, Cigarroa-Toledo N, Arana-Guardia R, Chi Chim WA, Chan Orilla JA, Machain-Williams C, et al. Mosquito fauna associated with Aedes aegypti (Diptera: Culicidae) in Yucatán State of southeastern México, and checklist with new records. Fla Entomol. 2016;99:703-9.

26. Richards SL, Anderson SL, Lord CC, Tabachnick WJ. Effects of virus dose and extrinsic incubation temperature on vector competence of Culex nigripalpus (Diptera: Culicidae) for St. Louis Encephalitis Virus. J Med Entomol. 2012;49:1502-6.

27. Ulloa A, Ferguson HH, Méndez-Sánchez JD, Danis-Lozano R, Casas-Martínez M, Bond JG, et al. West Nile virus activity in mosquitoes and domestic animals in Chiapas, Mexico. Vector Borne Zoonotic Dis. 2009;9:555-60.

28. Elizondo-Quiroga D, Davis CT, Fernandez-Salas I, Escobar-Lopez R, Velasco Olmos D, Soto Gastalum LC, et al. West Nile Virus isolation in human and mosquitoes, Mexico. Emerg Infect Dis. 2005; 11:1449-52.

29. Scherer WF, Dickerman RW, Diaz-Najera, Ward BA, Miller MH, Schaffer PA. Ecologic studies of Venezuelan encephalitis virus in southeastern Mexico. 3. Infection of mosquitoes. Am J Trop Med Hyg. 1971;20:969-79.
30. Farfán-Ale JA, Loroño-Pino MA, Garcia-Rejon JE, Soto V, Lin M, Staley M, et al. Detection of flaviviruses and orthobunyaviruses in mosquitoes in the Yucatan Peninsula of Mexico in 2008. Vector Borne Zoonotic Dis. 2010;10:777-83.

31. Garcia-Rejon JE, Ulloa-Garcia A, Cigarroa-Toledo N, Pech-May A, Machain-Williams C, Cetina-Trejo RC, et al. Study of Aedes aegypti population with emphasis on the gonotrophic cycle length and identification of arboviruses: implications for vector management in cemeteries. Rev Inst Med Trop Sao Paulo. 2018;60:e44.

32. Eiras AE, Pires SF, Staunton KM, Paixão KS, Resende MC, Silva HA, et al. A high-risk Zika and dengue transmission hub: virus detections in mosquitoes at a Brazilian university campus. Parasit Vectors. 2018;11:359.

33. Trout Fryxell RT, Freyman K, Ulloa A, Hendricks B, Paulsen D, Odoi A, et al. Cemeteries are effective sites for monitoring la crosse virus ( $\mathrm{LACv}$ ) and these environments may play a role in LACv infection. PLoS One. 2015;10:e0122895. 